\title{
16 In The Mood for Love: Intersections of Hong Kong Modernity
}

\section{Audrey Yue}

\section{INTERSECTION AND MODES OF PRODUCTION}

Hong Kong, 1962. Two neighbours meet and seek solace in each other as they discover their respective spouses are having an affair. They play-act what they will say to their spouses when they confront them with what they know. As they begin to spend more time together, they soon find that they too are falling in love and drifting into an affair. To allay neighbours' gossip, one moves to work as a reporter in Singapore. Four years later, in Cambodia covering General de Gaulle's visit, he finds himself unburdening the secret of this affair.

The above synopsis of Wong Kar-wai's In the Mood for Love (IMFL) reveals three sites of intersection. First, there is the theme - the mood of love is rendered through the intersection of the sanctity of marriage and the restraint of the affair. Second, there is the space - the narrative of the story is structured through Hong Kong's intersection with its region, including Cambodia, Singapore and Thailand (where the film was shot). Third, there is the time - history is replaced by a Jamesonian display of post-modern historicism, where the past surfaces as an intersection through the aesthetics of style.

The device of the intersection is a Wong Kar-wai hallmark. He has used two parallel stories since his directorial debut in 1988: triad big brother Ah Wah and his younger buddy-lackey, Fly, in As Tears Go By; teddy boy Yuddy and the cop-sailor in Days of Being Wild; cop 663 and 223's relationships with their respective lovers in Chungking Express; the hit man and his assistant in Fallen Angels; Evil East and Poison West in Ashes of Time; and Yiu-fai and Baowing in Happy Together. Ackbar Abbas formulates this as 'metonymic substitution', a device of doubling where characters are interchangeable in a narrative cycle of repetition. ${ }^{1}$

$I M F L$ features a similar parallel-story structure, with reporter Chow Mo-wan (Tony Leung Chiuwai) and housewife $\mathrm{Su} \mathrm{Li}$-zhen, usually referred to as 'Mrs Chan' (Maggie Cheung Man-yuk). Instead of Wong's usual protagonists' voice-over monologues interweaving the narrative, the film follows his period martial arts epic, Ashes of Time, by opening and ending with titles quoting from popular fiction:

It is a restless moment.

She has kept her head lowered,

To give him a chance to come closer.

But he could not, for lack of courage.

She turns and walks away.

That era has passed.

He remembers those vanished years.

Nothing that belonged to it exists any more.

As though looking through a dusty window pane,

The past is something he could see, but not touch.

And everything he sees is blurred and indistinct.

This adapted narration from Liu Yichang's novella Duidao reveals the three sites of intersection: a theme evoking a mood about two lovers and their failed encounter, a story that spatialises here and there, and a temporality that freezes memory in a perpetual present. ${ }^{2}$ Wong explains the significance of intersection in a book accompanying IMFL:

The first work by Liu Yichang I read was Duidao. The title is a Chinese translation of tête-bêche, which describes stamps that are printed top to bottom facing each other. Duidao centres round the intersection of two parallel stories - of an old man and a young girl. One is about memories, the other anticipation. To me, tête-bêche is more than a term for stamps or intersection of stories. It can be the intersection of light and colour, silence and tears. Tête-bêche can also be the intersection of time: for 
instance, youthful eyes on an aging face, borrowed words on revisited dreams. ${ }^{3}$

This essay takes Wong's evocation of tête-bêche as a point of departure for an exploration of intersection in the film. Two practices of tête-bêche as intersection are evident in IMFL. First, tête-bêche is the intersection of Duidao and IMFL. The film intersects with the novella through the cinema, the space of Hong Kong and China, and popular media from Hong Kong, Taiwan, and South-east Asia. ${ }^{4}$ Second, têtebêche resonates with the temporality of Hong Kong before and after 1997, when the British colony returned to its socialist motherland, China. I have written elsewhere about how Hong Kong cinema expresses this temporality of pre-post-1997 as a culture that simultaneously forecasts and recollects. ${ }^{5} \mathrm{I}$ extend that idea here, to suggest that intersection functions as a point in Hong Kong's period of transition - both pre-1997 to Chinese rule and post1997 in the following fifty years of the unique 'one

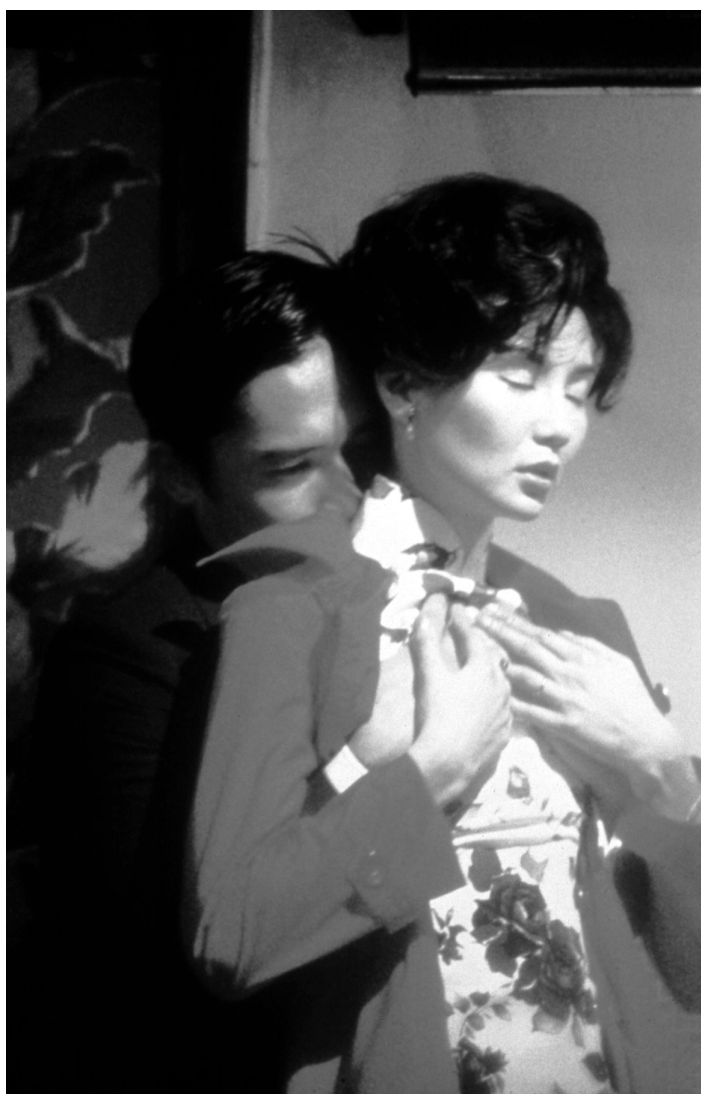

In the Mood for Love: Tony Leung and Maggie Cheung. country, two systems' administration. This can be seen in IMFL's conception and release. The film originated when Wong visited Beijing for a month in 1996, and he gave it the working title Summer in Beijing. He writes: 'Between Summer in Beijing and In the Mood for Love, eras changed, locales changed, and the music changed. We moved from contemporary jazz to nostalgic waltz.' ${ }^{6}$ IMFL is Wong's first post1997 film, shot on location in Thailand while filming 2046, a science-fiction film set fifty years after Hong Kong's 1997 return, highlighting its status as a product of temporal (before and after 1997) and spatial (China, Hong Kong and South-east Asia) intersections. In IMFL, '2046' is the number of the hotel room occupied by Chow.

These two practices of tête-bêche produce intersection as a point in transition characterised by convergence and divergence. In the next section below, I use convergence to explore the cinema. I critically review the politics of recent theorisation of Hong Kong cinema to interrogate how the mood of the popular is produced in the global reception of IMFL. In the section after that, I use divergence to examine the space between Hong Kong and China by exposing how the film uses Asian popular media to construct Hong Kong's relationship to the region. I argue that convergence and divergence question the presumed intersections of Hong Kong modernity. $I M F L$ captures this modernity as that which is accented by its specific history of emergence. My conclusion addresses the politics of its present by evaluating the film's temporality through its aesthetics of style.

\section{A THEME OF CONVERGENCE: IN THE MOOD FOR THE HONG KONG POPULAR}

Convergence is a practice synonymous with media globalisation. In the past five years or so, the globalisation of Hong Kong cinema has witnessed the popularity in the West of the industry's martial arts action genre, which has resulted in Hollywood produced blockbuster 'remakes', celebrity advertising and the emergence of a new breed of pan-Asian superstars in Hollywood. Against such a backdrop, the Wong Kar-wai film has also gained popularity, through the patronage of the likes of Quentin Tarantino and the art-house and independent festival circuits. Using convergence as the first moment of 
intersection, I suggest here that the Wong Kar-wai genre functions as a site that crosses the high-low divide stereotyping Hong Kong action cinema in the West. I argue that as a site of convergence, the genre reveals the practices of current Hong Kong cinema theorisation and consumption to expose the politics surrounding Hong Kong cinema's transnational success. This success is the result of Hong Kong's transition that has witnessed the migration of people, cinema and industry throughout the world.

$I M F L$ was released internationally in 2000 and 2001, around the same time as Ang Lee's awardwinning Crouching Tiger, Hidden Dragon. Equally as critically acclaimed, the film's numerous awards included Best Actor (Leung) and Grand Prix technique (Christopher Doyle, Mark Li Ping-Bin and William Chang) at Cannes 2000 and Best Actor, Best Actress (Cheung), Best Costume Design (Chang), Best Art Direction (Chang) and Best Editing (Chang) at the 20th Hong Kong Film Association Awards. These accolades attest to Wong Kar-wai's popularity. After the licensing of Fallen Angels to thirty-four countries in 1994, his UCLA interview with Tarantino in 1995, and the US release of Chungking Express in 1996, Wong's meteoric rise was unprecedented, culminating with the Best Director award for Happy Together at Cannes 1997, on the eve of Hong Kong's return to Chinese rule. IMFL crossed the high-low divide in 2000 when it was listed in various global annual top-ten film polls. ${ }^{7}$

As art-house, Wong's films repeat the comfort of a familiar formula. But as 'Hong Kong art-house', they disrupt the larger generic economy. The prefix 'Hong Kong' is a signifier of difference, as a postmodern and post-colonial space that attenuates the gap between cult and mass, and hip and unhip. As a practice of convergence between action and art, the Wong Kar-wai genre exposes the politics of the Hong Kong popular. It modulates the cult of martial arts films and the mass appeal of the new Hollywood action by suggesting that there is a difference between what is 'hip' and 'unhip' in the global consumption of Hong Kong cinema. By problematising the Hollywood-produced action blockbusters of Jackie Chan and John Woo as mass and almost B-list unhip, the genre's hipness produces the Hong Kong popular as a mood that structures a mode, reflecting the intersections of the post-modern collapse of categories, the global celebration of difference and the neo-colonial new modern. The film's theme - its mood - governs this structure.

Most popular reviews of IMFL speak of it as 'a veritable mood piece'. ${ }^{8}$ It communicates claustrophobic desire. Bound by the legal union that a marriage demands and the transgression of an illicit affection, Mr Chow and Mrs Chan try to curb their emotions. Claustrophobia is literalised through tight shot composition. Alleyways are angled from the turns of corners whilst interior shots of the apartments and the rooms are encased by windows, corridors, stairways and hallways, with characters framed through mid-shots, small tilts and slight pans. Yearning is structured through the finesse of Chang's editing and cinematography - a brush of fabrics, a turn of looks, a change in the film speed and tempo.

Theorisations of Wong's films have attributed the claustrophobic effect of his trademark fish-eye wideangle lenscape to his unique understanding of the city. ${ }^{9}$ These theorisations consign the city to a subject and a subjectivity by pointing to a prevailing Hong Kong structure of feeling concerning intensity, proximity and modernity. Some of these celebrate Wong's style often at the expense of undermining the specificity of Hong Kong, where the Hong Kong popular emerges only as a mood that is hip in current theorisations about the cinema and as a mode that structures a genre of film, maintaining the universality of film-as-art formula. ${ }^{10}$ It is ironic that the modernity of Hong Kong that is used to characterise Wong's style is now the same site used to wipe out the specificity of the Hong Kong locality. For example, writing about the post-modern hipness of IMFL, Teo suggests that the privileging of 'abstraction rather than plot' allows the audience to engage in 'a ritual of transfigured time ... and ... each member of the audience, depending on their ages, could in theory go as far back in time as they wish to the moment that holds the most formative nostalgic significance for them'. ${ }^{11}$ Abstractions such as this deny the politics demanded by the transfiguration of Hong Kong modernity's 'emergence of qualitatively new desires, social relations, and modes of association within the ... community ... and between that group and its ... oppressors. ${ }^{12}$

Such a politics consists of a desire to enact new modes of expression consequent on exposing the internal fissures of the transition. Elsewhere, I have argued that the politics of transition has produced a 
cinema post-1984 (the year of the Sino-British Joint Declaration that announced British Hong Kong's 1997 return to Chinese rule) that expresses Hong Kong's post-colonial identity as modern, mobile, transnational and hybrid. Both Hong Kong action and art-house films have emerged in such a milieu as instances of their own socio-cultural circumstances: the former, a high-octane genre that resonates with Hong Kong's panic culture and saw the emergence of the first modern, romantic-thriller, gangster hero (e.g. Chow Yun Fat in John Woo's 1984 A Better Tomorrow); the latter, the maturity of a style and an indigenous subject matter that achieved international acclaim and recognition.

I extend this here, to suggest that in $I M F L$, the mood of claustrophobia can be read as an effect of the inscription of phobic spaces by a transnational film-maker such as Wong, reflecting his experience of 'liminality and multifocality'. ${ }^{13}$ This is evident in both the film-maker's intent and his filmic strategies. Of IMFL, Wong noted that he was influenced by his own experience as an immigrant child growing up in the 1960s in Hong Kong amongst the diasporic Shanghainese community where rumours, lies and gossip were rife and people tried to pretend that all was well. Gossip and pretence are anchored in the film through Mrs Suen's disapproval of Mrs Chan's late nights out alone, the protagonists' make-believe marriages and play-acting of their partners' infidelity. These events mediate social order (duty, propriety, monogamy) and disorder (love affairs, extra-marital relationships, adultery) and encode, in the process the subjectivity of claustrophobia. As noted earlier, the film's formal strategies attest to this desire.

More significantly, this desire is the desire for a forbidden love that has to remain a secret. Hence, the film is an ode to the acting of acting where everyday practices such as eating and walking are denaturalised to convey the oscillation between feeling secure and trapped. Not surprisingly, the use of Shigeru Umebayashi's 'Yumeji's Theme' as the main love theme for the encounters between $\mathrm{Mr}$ Chow and Mrs Chan captures the breathlessness of this desire. In these sequences, the camera pans are longer and wider, and the movement stylised and slowed. Rather than displacing intimacy to outside public spaces as Abbas and Siegel have suggested about Wong's earlier films, these sequences punctuate the film through the labour of its haunting rhythm, and function as a non-diegetic (interstitial) space for the consummation of love. ${ }^{14}$ Clearly, this non-diegetic space returns to the liminality of Hong Kong-in-transition, as a third 'border' space caught between the East and the West. Here, the politics of transnationality exposed by the popularity of the Wong Kar-wai genre helps return the film to its cultural location. The following section further suggests, maybe ironically, that IMFL returns to Hong Kong via the mobility of transnational routes engendered by Asian popular media, only to produce a space of regionality.

\section{A PROJECT OF DIVERGENCE: REGIONALITY AND MODERNITY}

Jeffrey Ressner's Time International report on the 'controversy' created by IMFL - together with Ang Lee's Crouching Tiger, Hidden Dragon, Jiang Wen's Devils on the Doorstep, Shinji Aoyama's Eureka and Edward Yang's $Y i$ Yi - at Cannes exposes regionality as a benchmark for measuring standards of acceptability. ${ }^{15}$ Its headline, 'Asia Scores: The Region's Movies Come of Age at the Cannes Festival, with Four Big Awards', foregrounds the discourse of regionality as part of the politics of transnationality. The article once again marks 'Asia' as the other evaluated against the normative orthodoxy of international film acclaim. 'Coming of age' is an event that intersects the disjunctive projects of Western and Asian modernities as claims to both representation (of the films) and self-representation (from the films). This section shows how regionality is produced in IMFL through the emergence of Hong Kong modernity.

Regionality highlights divergence through the reterritorialisation of place as an effect of the cultural-economic contradictions of globalisation. The changing geopolitical configurations of Asia and Europe have witnessed culturalist, statist and economic projects of self-representation that construct new regional imaginations to patch the fissures of identity and difference. ${ }^{16}$ Against such a backdrop, regionality produces the image as a practice of the transnational imagination, as a way of negotiating between different sites, individuals, and agencies. ${ }^{17}$

IMFL belongs to such an imagination where, as the previous section has shown, the 'hipness' of the Wong Kar-wai genre has produced an image of style. I argue that this image is characterised by a panAsian pastiche of Eastern and Western influences. 
These influences question the authenticity of cultures and the different histories of the West in Asia. In $I M F L$, this pastiche is evident not only in the nostalgic 1960s mise en scène (e.g. modern apartments, modular furniture, pattern-design and floral wallpapers) but also in the use of Asian popular media. This use locates and problematises Hong Kong as an intersection for regional flows. As a strategy of divergence, intersection shows how the hegemony of Hong Kong cinema mobilises the process of reterritorialisation to produce its cultural location as a centre for Asian popular culture.

The eclectic references to Asian popular media in the film highlight Hong Kong as a modern space of regional cultural mix. For example, the use of Liu's Duidao archives an indigenous literary tradition in Hong Kong. A Shanghainese immigrant like Wong, Liu is one of Hong Kong's leading fiction writers. He is also the founder and chief editor of the journal, Hong Kong Literary Monthly (xianggangwenxue).The protagonists' penchant for reading martial arts pulp serials and Mr Chow's desire to write one himself show the popularity of the genre, one that Wong has also referred to in his use of Jin Yong's Eagle Shooting Heroes in Ashes of Time. Wong's quotations inscribe not only local literature and vernacular pulp fiction, but also Japanese film, art and music. 'Yumeji's Theme' is borrowed from Suzuki Seijun's 1991 film, Yumeji, a bio-fantasy about the turbulent life of Japanese artist Takehisa Yumeji (1884-1934), played by popular singer Kenji Sawada, who embodied the romanticism of Japan's Taisho era (1912-1926) with his hybrid woodblock and art nouveau style, and was renowned for his sketches of nude women. Other influences include the use of Cantonese, Beijing and Zhejiang operas. Notably, the recorded excerpts of silangtanmu and sangyuan jizi pay tribute to Tan Xin Pei, a legendary figure in the Beijing opera who was also involved in Ding Jun Shan (1905), China's first indigenous film.

Clearly, Wong's pastiche samples images and sound bytes from the present and the past, producing Hong Kong as a modern space constructed by its location as an intersection for regional Asian influences. In particular, I argue that the strategy of divergence reterritorialises the space between Hong Kong and China by engendering the image through the female voice and the female star as constitutive sites for the emergence of Hong Kong modernity.
First, the space between Hong Kong and China is rendered through Shanghai in the film. The story partially uses Shanghainese and is set in an immigrant Shanghainese community where everybody knows each other. The advent of Chinese communism in 1949 saw the fall of Shanghai with the emigration of its people and capital and the consequent emergence of modern Hong Kong. Since the 1997 return and China's vigorous economy, Shanghai has returned to its former status as the more 'senior' city in the Chinese cultural imaginary. Writing on heritage renewal projects in Shanghai and Hong Kong, Abbas suggests different histories of colonialism: Shanghai exhibits 'a cosmopolitanism of extraterritoriality' whilst Hong Kong displays 'a cosmopolitanism of dependency'. ${ }^{18}$ Although both forms of cosmopolitanism show how colonial presence is used to 'construct a Chinese version of modern cosmopolitan culture', ${ }^{19}$ I suggest here that the regionality of Shanghai rendered in the film complicates the chronology and shows the incommensurability of Chinese cultural history: the film functions as an axis of divergence revealing a Hong Kong modernity also shaped by the social imagination of Shanghai.

Hong Kong exists in the film as a space of displacement. Shot on location in Thailand because Wong could not find enough old buildings in Hong Kong, Hong Kong exists as an effect of two forces, migration and modernity. Both are evident in the narrative. Migration appears as Mrs Chan works for a shipping company selling tickets, Mr Chow leaves to work as a reporter in Singapore and Mrs Suen joins her family in America. Modernity appears, for example, in the use of radio broadcasts, Japanese electric rice-cookers, the telephone, and dining on steak and mustard sauce.

The setting of the film in 1962 is significant because the 1960s marked the beginning of Hong Kong's post-colonial modernity. Historian Frank Welsh dates Hong Kong's 'official' period of 'autodecolonisation' to 11 April 1963, when Hong Kong's House of Commons reviewed post-war Hong Kong. Welsh observes that it was in the 1960s that Hong Kong 'acquired what have become its typical modern attitudes: that single-minded dedication to moneymaking which powered the engine of expansion'. ${ }^{20}$ The film inscribes this history through the narrative by using the displacement of Shanghainese and South-east Asian migration, and the politics of tran- 
sition. Transition here is evident from the use of the archival footage of Charles de Gaulle's visit to Cambodia in 1966, on the eve of the Vietnam War and the start of China's Cultural Revolution, as a historical and metaphorical staging for Hong Kong, as a transit destination for Chinese migrants and IndoChinese and Vietnamese refugees, as well as for Hong Kong's 1997 return to Chinese rule.

The radio broadcast of popular 1930s and 1940s Shanghainese singer Zhou Xuan's 'Huayang de Nianbua' consolidates the film's narrative as a transitional history between Hong Kong and China. Indeed, the film even pays homage to the singer through its Chinese title, Huayang Nianhua. The practices of radio listening (and listening to imported music) and making song requests in the film highlights radio in the 1960s as a form of popular domestic technology. It also locates the popular memory of Zhou as Shanghai's 'golden voice' of the 1930s and 1940s. Her repertoire included more than one hundred songs. More significantly, she sang in the national language of Mandarin Chinese (putonghua). Jonathan Stock suggests that her use of the national language, along with radio broadcasts, and gramophone replays in nightclubs, restaurants and bars, 'mark [her] music as "popular"' through 'its intimate relationship with the mass media'. ${ }^{21}$ Andreas Steen states that she is placed at 'the heart of a cult of romantic nostalgia which has accompanied the growth of modern Shanghai since the early 1990s' ${ }^{22}$ The film's broadcast not only inscribes this history; its aurality functions as a technical device that disembodies Mr Chan's love through the cult of Zhou, relaying a romance with an image made present by technology as a female voice.

Another female voice in the film is that of Rebecca Pan, who plays the landlady, Mrs Suen. Like Zhou Xuan, Pan is also a Shanghainese who recorded songs in Mandarin and English in Hong Kong, but in the 1970s. IMFL's official website acclaims her as a Chinese popular music legend throughout East Asia. This legendary status is anchored in the film through her rendition of 'Bengawan Solo', the national song of Indonesia. Margaret Kartomi notes the post-colonial significance of this song not only in Indonesia but also in East and South-east Asia through its reflections on anti-colonial resistance and political independence. Tracing multiple renditions in Tagalog in the Philippines and in Cantonese or Mandarin in Singapore,
Hong Kong, Taiwan and China, she notes that it has been performed 'in virtually every popular style, from kroncong to swing, jazz to bossanova, rock-and-roll, national song to march band, and brass band to symphony orchestra', becoming 'a regional symbol' that represents 'the hegemony and power struggles within Indonesia and the East/Southeast Asia as a whole, with its economic dynamism and self-assertiveness'. ${ }^{23}$

This song anchors the arrival of Mr Chow in Singapore. An interior shot of his office pans across the Singapore Daily sign, echoing an earlier pan in Hong Kong of Mr Chow at his Sing Man Yit Pao Daily newspaper office. The references to print media further add to the film's narrative of modernity through its role as a technology for the formation of the modern nation-state. More significantly, this narrative of modernity also reveals a self-reflexive return to the cinema of Wong Kar-wai and the politics of its emergence where tête-bêche, as the intersection of Mrs Suen (Pan) and Mr Chow (Leung), functions as a form of binding between IMFL and Days of Being Wild. Styled with the same vaselined hair, attired in the same mod suit and tie, the intersection of Leung and Pan re-places the song through the intertextuality of Days of Being Wild. Hence, the use of Nat King Cole's 'Aquellos Ojos Verdes', 'Quizas Quizas Quizas' and 'Te Quiero Dijiste' in IMFL makes sense when rendered through the surface of the Philippines as an image without memory, a cultural plastic of sound bites that makes familiar the foreignness of style. Like the band musicians in Hong Kong's nighclubs that croon familiar, romantic and exotic Latin ballads, here post-modern historicism produces a presence of the image as style.

\section{CONCLUSION: AD(DRESS)ING ASIAN POP}

The modishness of Cheung's cheongsam dresses in the film also foregrounds this post-modern historicist practice of making the image present as style. Her costumes epitomise the temporality of the film as a form of presentness marked by the new, where the progress of time is ritualised in the changing of her wardrobe. This temporality connotes a dailiness accentuated through the ephemerality of fashion. The style of the dress is not only newly fashionable again in the global consumption of Chinoiserie. The actualisation of style is also heightened through the aestheticisation produced by slow pans, low speeds 
and close-ups. This exteriority reflects the image of the Wong Kar-wai genre as a cinema of style, speaking to the politics of global fashion tourism. However, its literalness not only translates the logic of cross-cultural exchange; the style of dress also locates a politics about the history of modern Hong Kong cinema. This is also the style of dress adorning Cheung in Centre Stage, a film archiving the life of the legendary pan-Chinese movie star Ruan Lingyu and the attendant emergence of film in Hong Kong. ${ }^{24}$ Cheung's performance won her the Best Actress Silver Bear award at the 1991 Berlin International Film Festival, considered as the first international acclaim for new Hong Kong cinema, but also marking the modernity of that cinema as one that questions the form of its relationship to the present and itself, signalling a self-consciousness about its presence in a world structured by the fissures of transition. Popularly described as the most recognisable female Asian face in the world, Cheung's image has not only appeared in films by Wong Kar-wai, Tsui Hark and Jackie Chan, but it also has currency as the face of the namesake style magazine, the hair of Lux shampoo advertisements and 'the latex fit' of French vampires ${ }^{25}$ (Irma Vep) and martial arts cult aficionados (Augustin, roi $d u$ Kung-fu). Her iconicity converges to address the Oriental, neo-Oriental and self-Oriental commodification of contemporary pan-Asian popular culture. It problematises the Hong Kong cinema interface as a form of marginal imperialism in the Asian region, ${ }^{26}$ a genre of fusion pan-Asian kitsch in the global imagination ${ }^{27}$ and a structure of mood in the nostalgic present. This is a cosmopolitan image that tells the modern story of the intoxication of love, but also a passion that returns to the politics of cinema, its look and its tale.

\section{NOTES}

\section{Ackbar Abbas, Hong Kong: Culture and the Politics of Disappearance (Minneapolis: University of Minnesota Press, 1997), 48-62. \\ 2. Liu Yichang, 'Intersections (Duidao)', trans. Nancy Li, Renditions, nos. 29-30 (1988): 92.}

3. Wong Kar-wai, Tête-bêche: A Wong Kar Wai Project (Hong Kong: Block 2 Pictures, 2000), no pagination. 4. Set in 1970s Hong Kong, Duidao tells the parallel stories of Chunyu Bai, an old reporter from Shanghai who fled to Hong Kong in the 1940s to escape the
Japanese Occupation, and Ah Xing, a young single woman who lives with her parents. Bai is nostalgic, fuelled by his memories of Shanghai, his youthful liaisons with dancehall girls and his failed marriage. Ah Xing is forward-looking. Always day-dreaming about herself as a famous singer or a movie star, she longs to find love and marry a handsome husband, someone 'a bit like Ke Junxiong, a bit like Deng Guangrong, a bit like Bruce Lee, and a bit like Alain Delon' (Liu, 'Intersections', 92). Triggered by songs, old photographs, and magazine covers and posters of movie stars, the two characters' temporalities are retrospective and projective. In the story, they only meet once sitting next to each other in a crowded cinema. Everyday practices like walking, commuting, listening to music, watching television and going to the movies highlight their close encounters. These practices construct Hong Kong, already a Chinese migrant enclave and a metropolis dizzy with escalating property prices and swirling in the popular media mix of Taiwanese Mandarin pop songs, Filipino renditions of American Top Ten hits, Hollywood cinema and French film icons. The oft-repeated phrase, 'a bit like Ke Junxiong, a bit like Deng Guangrong, a bit like Bruce Lee, and a bit like Alain Delon', epitomises the cultural mix. As this essay will show, these practices are also significant to $I M F L$, because they function as the film's historical and cultural mode of production.

5. Audrey Yue, 'Preposterous Horror: On Rouge, $A$ Chinese Ghost Story and Nostalgia', in The Horror Reader, ed. Ken Gelder (New York: Routledge, 2000), 365-399; 'Transition Culture in Clara Law's Autumn Moon: Refiguring the Migrant and the Foreigner', Intersections: <wwwsshe.murdoch.edu.au/intersections> no. 4 (2000) (20 September 2000); and 'What's so queer about Happy Together? aka Queer (N)Asian: Interface, Mobility, Belonging', Inter-Asia Cultural Studies Journal, 1, no. 2 (2000): 251-263.

6. Wong Kar-wai, 'From Summer in Beijing to In the Mood for Love', in Tony Leung: In the Mood for Love (Taiwan: Block 2 Music Co. \& Universal Music Ltd, 2000), no pagination.

7. For example, David Ansen, 'Ansen's Top 15: Our Critics Pick his Best and Brightest from the Pack', Newsweek, 14 January 2000: 58; Richard Corliss, 'Cinema (Arts and Media/The Best and Worst of 2001', Time International, 24 December 2001: 78; and Anthony D'Alessandro, 'Top Grossing Pics of 2001', Variety, 7-13 January 2002: 38. 
8. Stephen Teo, 'Wong Kar-wai's In the Mood for Love: Like a Ritual in Transfigured Time', Senses of Cinema: <www.sensesofcinema.com/contents/01/13/mood.html> (10 April 2001).

9. See for examples: Kent Jones, 'In the Mood for Love (Review)', Film Comment, 37, no. 1 (2001): 22. Teo refers to $I M F L$ reflecting 'an ideal dreamtime of Hong Kong' (ibid.). Abbas suggests that the city functions as 'leitmotif of a space that enforces physical proximity but forbids intimacy', and has become a protagonist that is only perceptible in 'fragments, metonymies, displacements', in 'Dialectic of Deception', Public Culture, 11, no. 2 (1999): 362-363. Marc Siegel extends this to show that it produces 'new kinds of intimacy' that exist 'outside in the public sexual world', in 'The Intimate Spaces of Wong Karwai', in At Full Speed: Hong Kong Cinema in a Borderless World, ed. Esther C. M. Yau (Minneapolis: University of Minnesota Press, 2001), 290, 285.

10. See Jones, 'In the Mood for Love (Review)'. See also Jean-Marc Lalanne, 'Images from the Inside', trans. Stephen Wright, in Jean-Marc Lalanne, David Martinez, Ackbar Abbas, Jimmy Ngai, Wong Kar-wai (Paris: Editions Dis Voir, 1997), 9-28; Ewa Mazierska and Laura Rascaroli, 'Trapped in the Present: Time in the Films of Wong Kar-wai', Film Criticism, 25, no. 2 (2000): 2-20.

11. Teo, 'Wong Kar-wai's In the Mood for Love'.

12. Paul Gilroy, The Black Atlantic: Modernity and Double Consciousness (London: Verso, 1993), 37; emphasis in original. Gilroy's counter-modernity relates to Hong Kong modernity as forms of alternative modernity. On alternative modernities, see also Dilip P. Goankar, 'On Alternative Modernities', Public Culture, 11, no. 1 (1999): 1-18.

13. Hamid Naficy, 'Phobic Spaces and Liminal Panics: Independent Transnational Film Genre', in Global/Local: Cultural Production and the Transnational Imaginary, ed. Rob Wilson and Wimal Dissanayake (Durham: Duke University Press, 1996), 130.

14. Abbas, 'Dialectic of Deception'; Siegel, 'The Intimate Spaces'.

15. Jeffrey Ressner, 'Asia Scores: The Region's Movies Come of Age at the Cannes Festival, with Four Big Awards - and, in Ang Lee's Martial-arts Fantasy, One Peerless Triumph', Time International, 115, no. 22 (2000): 54.

16. On 'Asia' as a discourse of regionality, see: Rob Wilson and Wimal Dissanayake, ed., Asia/Pacific as Space of
Cultural Production (Durham: Duke University Press, 1995); Chen Kuan-Hsing, ed., Trajectories: Inter-Asia Cultural Studies (London: Routledge, 1998); Aihwa Ong and Donald Nonini, ed., Ungrounded Empires: The Cultural Politics of Modern Chinese

Transnationalism (London: Routledge, 1997); Tu Wei-ming, ed., Confucian Traditions in East Asian Modernity (Cambridge, MA: Harvard University Press, 1996); Arif Dirlik, ed., What is a Rim? (Boulder: Westview Press, 1993); Ron Martin, ed., Money and the Space Economy (Chichester: John Wiley \& Sons, 1999); Kris Olds et al., ed., Globalisation and the Asia Pacific: Contested Territories (London:

Routledge, 1999); Myong-gon Chu, The Nerw Asia in Global Perspective (New York: St Martin's Press, 2000); and Leo Ching, 'Globalizing the Regional, Regionalizing the Global: Mass Culture and Asianism in the Age of Late Capital', Public Culture, 12, no. 1 (2000): 233-257.

17. Appadurai's disjunctive scapes point to the production of the image as a practice of transnational imagination, in 'Disjuncture and Difference in the Global Cultural Economy', Public Culture, 2, no. 2 (1990): 1-24. An example of this image in Asia is evident in Leo Ching's writings on mass Asianism.

18. Ackbar Abbas, 'Cosmopolitan De-scriptions: Shanghai and Hong Kong', Public Culture, 12, no. 3 (2000): 778 .

19. Ibid., 775 .

20. Frank Welsh, A History of Hong Kong (London: HarperCollins, 1994), 458, 461.

21. Jonathan Stock, 'Zhou Xuan: Early Twentiethcentury Chinese Popular Music', Asian Music, 26, no. 2 (1995): 123.

22. Andreas Steen, 'Tradition, Politics and Meaning in 20th Century China's Popular Music. Zhou Xuan: "When will the Gentleman Come Back Again?"' Chime, 14-15 (1999-2000): 150.

23. Margaret Kartomi, 'The Pan-East/Southeast Asian and National Indonesian Song Bengawan Solo and its Javanese Composer', Yearbook for Traditional Music (1998), 97-98.

24. On Centre Stage, see Brett Farmer, 'Mémoire en Abîme: Remembering (through) Centre Stage' (review essay), Intersections: Gender, History and Culture in the Asian Context, 4: (September 2000): <wwwshe.murdoch.edu.au/intersections/issue4/ centre_review.html> (10 October 2000); and Shuqin Cui, 'Stanley Kwan's Center Stage: The (Im)possible 
Engagement between Feminism and Postmodernism', Cinema Journal, 39, no. 4: (Summer 2000): 61-76; as well as Bérénice Reynaud's essay in this volume.

25. Olivia Khoo, “Anagrammatical Translations”: Latex Performance and Asian femininity unbounded in Olivier Assayas's Irma Vep', Continuum, 13, no. 3 (November 1999): 383-395.

26. Ding-Tzann Lii, 'A Colonized Empire: Reflections on the Expansion of Hong Kong Films in Asian Countries', in Chen, Trajectories, 122-141.
27. On the nature of commodity consumption in Wong Kar-wai’s other films, see Gina Marchetti, 'Buying American, Consuming Hong Kong: Cultural Commerce, Fantasies of Identity, and the Cinema', in The Cinema of Hong Kong: History, Arts, Identity, ed. Poshek Fu and David Desser (Cambridge, Cambridge University Press, 2000), 289-313. 


\section{University Library}

- MINERVA A gateway to Melbourne's research publications

Minerva Access is the Institutional Repository of The University of Melbourne

Author/s:

YUE, AUDREY

Title:

In the mood for love: intersections of Hong Kong modernity

Date:

2003

Citation:

Yue, A. (2003). In The Mood for love: intersections of Hong Kong modernity. In C. Berry (Ed.), Chinese Film in Focus: 25 New Takes (pp. 128-136). British Film Institute.

\section{Publication Status:}

Published

Persistent Link:

http://hdl.handle.net/11343/34511

File Description:

In the mood for love: intersections of Hong Kong modernity 


\section{University Library}

\section{- M M I N E R VA A gateway to Melbourne's research publications}

Minerva Access is the Institutional Repository of The University of Melbourne

Author/s:

YUE, Al

Title:

In the Mood for Love: Intersections of Hong Kong Modernity

Date:

2003

Citation:

YUE, A. I. (2003). In the Mood for Love: Intersections of Hong Kong Modernity. BERRY, C (Ed.). Chinese Films in Focus: 25 New Takes, (1), pp.128-136. British Film Institute.

Persistent Link:

http://hdl.handle.net/11343/25674 